\title{
Determination of Some Chemical Composition of Four Date Seeds From AL-Khums Libya
}

\author{
Nemat Allah Moftah AL-Tunsi, Salima Ali Eddeif, Atega Saeed AL-Jenkawi, Nadia Abdussalam Laswad, \\ Rabia Omar Eshkourfu and Samira Omar Hribesh* \\ Department of Chemistry of AL-Mergeb University, \\ AL-Khums, Libya
}

\begin{abstract}
The four date seeds of Ami, Raht, Omvitity and Taboni were analyzed for their moisture, ash and mineral composition. The moisture content was ranged between $5.09 \%$ and $10.09 \%$. The ash content was ranged between $0.95 \%$ and 2 $\%$. In addition, mineral analysis showed that Omvitity seeds had the high amount of potassium $844.9 \mathrm{mg} / \mathrm{L}$, followed by Ami, Taboni and Raht respectively. Whereas, other minerals of four date seeds were sodium that ranged $(14.1-56.3 \mathrm{mg} / \mathrm{L})$, zinc (0.411-0.703 mg/L), Copper (0.180-0.434 mg/L), Chromium $(0.00137-0.0014$ 0) and lead (0-0.535 mg/L). However, cadmium was not detectable of all seeds samples.
\end{abstract}

Keywords-Date seeds, chemical composition, minerals.

\section{INTRODUCTION}

Date palm (Phoenix dactylifera $\mathrm{L}$ ) is a major fruit tree grown in various countries in the world, in particular Middle Eastern countries. In addition, they play an important roles in the society, environment and economy for many people who live in dry regions of the world[1]. The date palm fruit consists of a seed and a thickly pericarp. The date seed which also known as pit or stone is 10-15\% weight of date fruit. As a date seeds were found as good sources for nutrition, economy and industry,[2,3] many researchers have been carry out to study their composition. Besbes and his workers, have reported that the Deglet Nour and Allig cultivars seed dates, respectively contain total carbohydrate 83.1 and $81.0 \%$ protein 5.56 and $5.17 \%$, ash 1.15 and $1.12 \%$ and fat 10.19 and $12.67 \%$ [4] The following values were also found for Khalti date seeds $8.12 \%$ total sugars, $6.88 \%$ moisture, $6.63 \%$ reducing sugars $1.49 \%$ sucrose, $5.31 \%$ protein and $8.33 \%$ fat [5]. Azodi and his group have shown that the seeds date of Kabkab and Shahani composed of $1.35 \%$ of ash $59 \%$ of lipid, $62.18 \%$ of fiber, $10.50 \%$ moisture and $5.56 \%$ of protein. However, the main components in the date seeds are carbohydrate and fat [6]. Date seeds were found to be excellent source of dietary fiber and their variety level was between 64.5 and $80.15 \mathrm{~g} / 100 \mathrm{~g}$ fresh weight [7]. Dietary fibers have vital applications for therapeutic implications such as, obesity, diabetes and hyperlipdemia [8]. Date seeds were found to contain many important minerals such as macro-elements : potassium, sodium, magnesium, phosphorus, calcium, they are also have micr-elements : chromium, cobalt, copper, zinc, nickel, iron, cadmium and lead $[3,9,10]$. The content of total mineral ions was compared with coffee, barely and Bahraini date seed, the results showed that , the highest content was in the coffee followed by barely and finally date seeds. These results appeared that the concentration of mineral ions in date seeds was in the nutritional intake level in humans [11]. Other Studies on date seeds have shown that they are composed of phenolic compounds which found to posses several advantages such as antimicrobial, antioxidant and anti-inflammatory [12]. In this paper we report four date seeds which known as Raht, Ami, Omvitity and Taboni from AL Khums-Libya and study their composition.

\section{MATERIALS AND METHODS}

Four date seeds of Raht, Omvitity, Taboni and Ami were collected from the palm trees of AL-khums city of Libya. The seeds were washed and dried under the sun and then were grinded to fine powder, next they was kept at room temperature in the tight container for required analysis. All chemicals in this study were purchased from BDH(ENGLAND) and Fisher chemical.

\section{a) Determination of moisture content}

One gram of the seed samples was placed into the uncovered crucibles and dried in the oven and then kept at $105^{\circ} \mathrm{C}$ for three hours. The dried sample is next weighed to a constant weight. This process is repeated three times to reach the constant weight [13].

The moisture percentage in date seeds $=$

$$
\frac{\text { lossed wieght of date seed }}{\text { initial wieght of sample taken }} \times 100
$$

\section{b) Determination of ash content}

Two grams of dried seed sample was taken in triplicate and the residual weight was obtained by placing the sample in pre-weighed crucibles and ashed at $550^{\circ} \mathrm{C}$ in the muffle furnance for 6 hours until a constant weight is reached [13].

The percentage of ash in date seeds $=$

$$
\frac{\text { wieght of residue ash }}{\text { initial wieght of sample taken }} \times 100
$$

\section{c) Determination of mineral contents}

The seed samples were prepared for macro-elements (sodium, potassium) and micro-elements (lead, cadmium, zinc, copper and chromium) using standard methods Association of Official Analytical Chemist (AOAC)[13]. Two grams of seed samples were converted to ash, then were dissolved in $5 \mathrm{ml}$ of 
$0.1 \mathrm{~N}$ nitric acid . The solution was next diluted with distilled water to reach the desired volume. The sodium and potassium concentrations were measured by flame atomic emission, whereas, lead, cadmium, zinc, copper and chromium concentrations were measured by atomic absorption spectrophotometer. After that, the intensity of emission was measured and a calibration curve was plotted to determine the concentration of the elements.

\section{RESULTS AND DISCUSSION}

Table 1 shows the results of moisture composition of four date seeds of Ami, Raht, Taboni and Omvitity, which ranged between $5.9 \%$ and $10.09 \%$. The highest moisture content was for Ami and with no significant difference between Raht, Taboni and Omvitity. Previous studies have been reported moisture content $3.10 \%-12.5 \%$. This indicates that, our results were similar with the previous studies [14.15]. The ash content of seeds samples was found as following $2 \%$ Raht, 1,96\% Omvitity, $1.86 \%$ Taboni and $0.95 \%$ Ami. Raht was the highest ash percentage whereas Ami was the lowest. Therefore, Raht may be rich in inorganic compounds. These results were in comparable with earlier studies of Amany and Nwaokobia [16,17].

Table 1. The moisture and ash contents of four seeds samples

\begin{tabular}{|c|c|c|c|c|}
\hline Component & Taboni & Raht & Omvitity & Ami \\
\hline Moisture & $5.96 \%$ & $10.09 \%$ & $5.09 \%$ & $6.85 \%$ \\
\hline Ash & $1.86 \%$ & $2 \%$ & $1.96 \%$ & $0.95 \%$ \\
\hline
\end{tabular}

The results of this study clearly show that date seeds have important mineral contents as shown in table 2. The most abundant mineral elements found in the date seed was macro elements such as potassium which is arranged between (194.8- 844.9 mg/L) followed in descending order by sodium (14.1 -56.3 mg/L).

Table 2.The minerals concentration $(\mathrm{mg} / \mathrm{L})$ of four date seeds samples.

\begin{tabular}{|c|c|c|c|c|}
\hline \multirow{2}{*}{ Minerals } & \multicolumn{4}{|c|}{ Seeds Samples } \\
\cline { 2 - 5 } Sodium & Ami & Taboni & Raht & Omvitity \\
\hline Potassium & 56.3 & 29 & 14.1 & 37.9 \\
\hline Zinc & 0.411 & 0.5 & 0.703 & 0.541 \\
\hline Copper & 0.228 & 0.293 & 0.180 & 0.434 \\
\hline Chromium & 0.00140 & 0.00137 & 0.00137 & 0.00138 \\
\hline Cadmium & 0 & 0 & 0 & 0 \\
\hline Lead & 0.178 & 0.0465 & 0.535 & 0 \\
\hline
\end{tabular}

Ami and Omvitity were found to be rich in potassium and sodium as seen in Fig 1 ,therefore, the high potassium to sodium content may be of health importance to patients with heart diseases [18]. These results of potassium concentration is slightly higher compared with previous studies of Mohamed and Khamis which was $(542.20 \mathrm{mg} / \mathrm{L})$ [19]. This difference may due to different seed varieties, harvest time and the use of fertilizer [20].

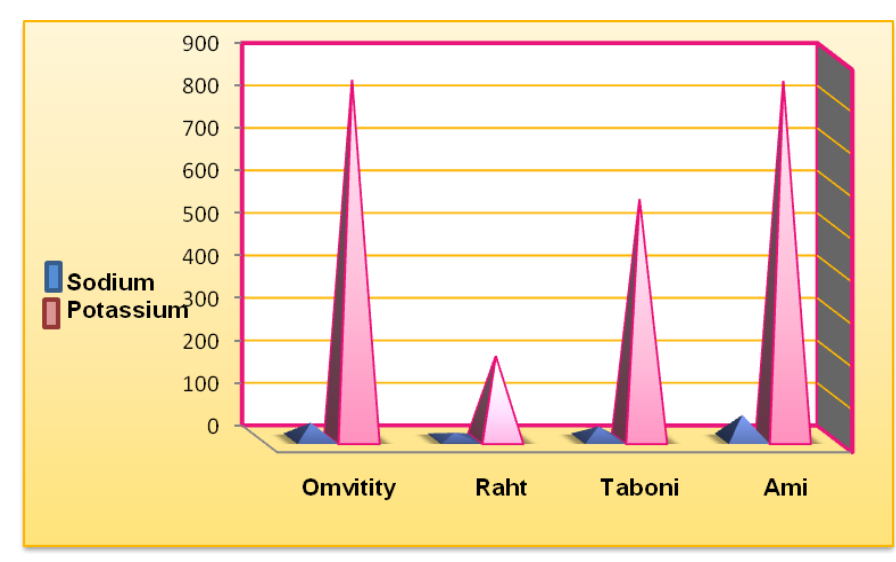

Figure 1. Comparison of sodium and potassium concentration of seeds samples.

Table 2 also shows microelements of date seeds (zinc, copper, chromium, cadmium and lead) which were in varying concentration. Zinc concentrations of date seeds were at the high levels compared with those of others (0.703- 0.541 $\mathrm{mg} / \mathrm{L}$ ) as shown in Fig 2. These obtained findings from this study are in close agreement with earlier results of Mexico date seeds [21].

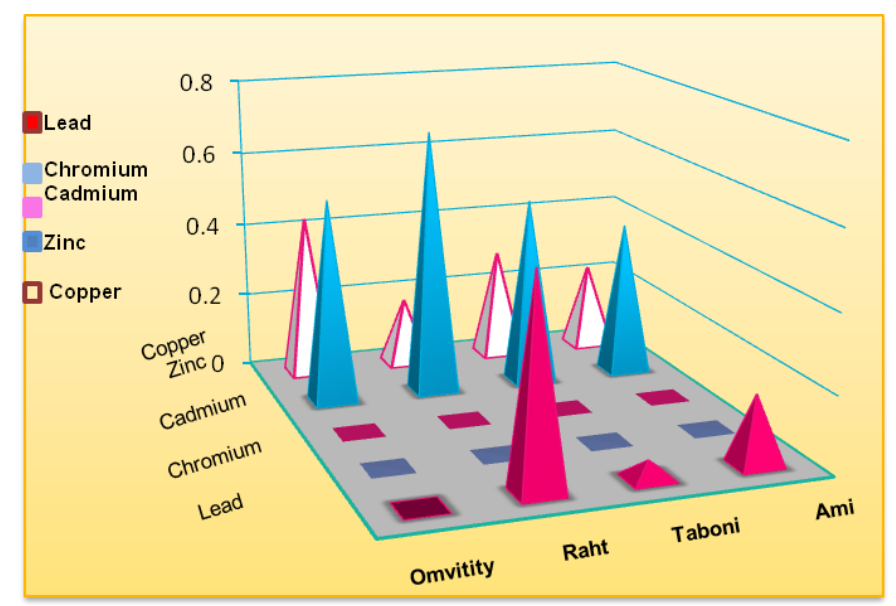

Figure 2. Comparison of (zinc, copper, chromium, cadmium and lead) concentration of four seeds samples.

Moreover, copper, chromium, cadmium and lead were at low concentration that is ranged between $(0-0.434 \mathrm{mg} / \mathrm{L})$. The proximate analyses value of date seeds found in the present work are within the range of values presented earlier in the literature [22]. These results show that Omvitity seed may be better for health as it has no lead and cadmium. Those, elements are known as toxic to human health when their concentrations is high in food matter [23]. On the other hand, Raht has high concentration of lead, therefore, it may be less considerable as good for consuming food, however, the high concentration of lead might because the date palm near to the road that polluted by heavy cars [24]. 


\section{CONCLUSION}

In summary, the results of this study revealed that moisture and ash was highest in the Raht, followed by Ami, Taboni and Omvitity. Moreover, the finding of minerals content suggested that date seeds can be used in the diet as they contain potassium, sodium and zinc.

\section{REFERNCES}

[1] Mustafa A. I., Hamad A. M. and Al-Kahtani M. S. Date variety for jam production. In proceeding of the first symposium on the date palm in Saudi Arabia. King Faisal University, AL-Hassa, (1983), $552-558$

[2] S. Sirisena.S, Ng, K and Ajlouni.S. Comprehensive Reviews in Food Science and Food Safety, (2015), 14(6), 813-823.

[3] A. Golshan Tafti, N. Solaimani Dahdivan, and S.A.Yasini Ardakani, International Food Research Journal(2017), 24(4), 1399. 1406.

[4] S. Besbes, C. Blecker, C. Deroanne, N.E. Drira and H. Attia. Date seeds: chemical composition and characteristic profiles of the lipid fraction. Food Chemistry. (2004a) 84, 577-584.

[5] E.B. Saafi, M.Trigui, R. Thabet, M. Hammami and L. Achour. Common date palm in Tunisia: chemical composition of pulp and pits. International Journal of Food Science and Technology. (2008), 43, 2033- 2037.

[6] R.Amir Azodi, M. Hojjatoleslamy and M.A.Shariati. Comparison of chemical properties of Kabkab and Shahani palm kernel. Malaysian Journal of Scientific Research. (2014), 1, 17-19.

[7] M.A. Al-Farsi and C.Y.Lee. Optimization of phenolics and dietary filre extraction from date seeds. Food chemisty.(2008), 108, 977 985 .

[8] N.Tariq, D.J. Jenkins, E.Vidgen, N. Fleshner, C.W.Kendall, J. Story, W.D. Singer, M.Costa and N.Struthers. Effect of soluble and insoluble fibre diets on serum prostate specific antigen in men. Journal of Urology. (2000), 163,114-118.

[9] L.A.Abdillah and M.Andriani. Friendly alternative healthy drinks through the use of date seeds as coffee powder. Paper presented at the Proceeding of ICEBMUntar Jakarta.(2012).

[10] M.J.Abdul Afiq, R.Abdul Rahman, Y.B.Che Man, H.A. AlKahtani and T.S.T.Mansor. Date seed and date seed oil. International Food Research Journal.(2013), 20, 2035-2043.

[11] A.Y.Ali-Mohamed and A.S.H. Khamis. Mineral ion content of the seeds of six cultivars of Bahraini date palm (Phoenix dactylifera). Journal of Agriculture and Food Chemistry. (2004),52, 6522-6525.

[12] F.Shahidi and M. Naczk. Phenolics in food and nutraceuticals. Boca Raton, FL: CRC Press, (2004)

[13] Association of official analytical chemists . Official methods of Analysis .13th ed A.O.A.C Washington, DC. USA. (1980).

[14] M.S.Rahman, S.Kasapis , N.S.Z.Al-Kharusi , I.M .Al-Marhubi and A.J .Khan, Composition characterization and thermal transition of date pits powders. J. Food Eng., (2007), 80, 1-10.

[15] S.Suresh , N.Guizani, M.Al-Ruzeiki , A.Al-Hadhrami , H.AlDohani ,L. Al-Kindi and M.S. Rahman, Thermal characteristics, chemical composition and polyphenol contents of date-pits powder. J. Food Eng., (2013), 119, 668-679.

[16] M. M. B.Amany, M. A Shaker and A. K Abeer. Antioxidant activities of date pits in a model meat system. International Food Research Journal.(2012), 19: 223- 227.

[17] K. Nwaokobia, R. O. Ogboru and C. A. Idibie Investigating the Proximate, Ultimate and Chemical Composition of Four Cultivars of Date Seed, Phoenix dactylifera L. World News of Natural Sciences. (2018), 18(2), 52-61.

[18] I.A.Mahmud, M.E.S.Mirghani, M.F.R.Alkhatib, F.Yusof, M Shahabuddin,O .Rashidi, and Daoud, Jamal I.Nutrients depictions of Barhi date palm (Phoenix dactylifera L.) kernels. International Food Research Journal. (2017), 24, S325-S334.

[19] A. Y.Ali-Mohamed and A. S. H .Khamis. Mineral ion content of the seeds of six cultivars of Bahraini date palm (Phoenix dactylifera). Journal of Agriculture and Food Chemistry. (2004),52 , 6522-6525.

[20] N. Chaira , A.Ferchichi ,A Mrabet and M.Sghairoun. Chemical composition of the flesh and pit of date palm fruit and radical scavenging activity of their extracts. Pakistani J. of Biological Sciences.(2007), 10, 2202-2207
[21] R. Salomón-Torres, N.Ortiz-Uribe, B.Valdez-Salas, N. RosasGonzález, C. García-González, D.Chávez, I.Córdova-Guerrero, L.Díaz-Rubio, M. del Pilar Haro-Vázquez, J. Luis MijangosMontiel, A. Morales-Maza, P. Mahadevan and R. Krueger. Nutritional assessment, phytochemical composition and antioxidant analysis of the pulp and seed of medjool date grown in Mexico. PeerJ.(2019),6821.

[22] A. Y .Ali-Mohamed and A. S. H Khamis. Mineral ion content of the seeds of six cultivars of Bahraini date palm (Phoenix dactylifera) Journal of Agriculture and Food Chemistry. (2004), 52, 6522-6525.

[23] L.Järup. Hazards of heavy metal contamination Brit. Med. Bull (2003), 68 (1), 167- 182

[24] I. M .Aldjain, M. H .Al-Whaibi, S. S .Al-Showiman and M.H.Siddiqui. Determination of heavy metals in the fruit of date palm growing at different locations of Riyadh. Saudi Journal of Biological Sciences, 2011.18; 175-180. 